\title{
KARAKTERISTIK PEMAHAMAN MAHASISWA DALAM MENGONSTRUKSI BUKTI MATEMATIS
}

\author{
Syamsuri $^{1}$, Cecep AHF Santosa ${ }^{2}$ \\ ${ }^{1,2}$ Jurusan Pendidikan Matematika FKIP-Universitas Sultan Ageng Tirtayasa Banten
}

\begin{abstract}
The teaching and learning process in the mathematics undergraduate program emphasizes on the use of an axiomatic system and formal deduction. In this process, the students learn continuously about mathematical evidence, which can be referred to as the ability to build arguments based on their mathematical understanding. This article aims at describing the characteristics of students' comprehension in constructing a mathematical evidence. A qualitative approach is applied in this study, which involves third year students of Mathematics Education Department at the state university in Banten. Interviews are conducted to find out and clarify how the students construct and build mathematical evidence. The result shows that the students' mathematical proof of comprehension can be classified into three types: holistic-global, partial-global, and partial-local. It is expected that the result of the study can be used as a source of consideration in determining appropriate learning strategies that can overcome students' difficulties in constructing a mathematical evidence.
\end{abstract}

Keywords: Proof of comprehension; Holistic-global; Partial-global; partiallocal.

\section{PENDAHULUAN}

Pembelajaran matematika di perguruan tinggi menekankan pada sistem aksiomatik dan deduksi-formal. Pada pembelajaran matematika tingkat lanjut ini, para mahasiswa banyak mempelajari bukti-bukti matematis. Bukti matematis tersebut terdapat dalam buku-buku teks maupun disampaikan oleh para dosen di depan kelas saat pembelajaran. Oleh karena itu, diperlukan pemahaman matematis agar para mahasiswa tersebut mampu menguasai materi matematika pada tingkat ini.

Pembelajaran tentang pembuktian matematis di perguruan tinggi telah banyak dikaji oleh para peneliti (Galbraith, 1981; Raman, 2003; Alcock \& Weber, 2004; Larsen \& Zandieh, 2008; Alcock \& Inglis, 2008; Stylianides \& Stylianides, 2009; Weber, 2012; Zazkis, et al., 2015; Syamsuri, et al., 2016; Lee, 2016). Hal ini menunjukkan bahwa mahasiswa yang masuk pada jenjang perguruan tinggi harus mengembangkan pengetahuan matematika secara formal. Bukti formal (formal proof) tersebut mengacu pada bentuk logika yang akurat atau mengacu pada bentuk bukti yang digunakan oleh matematikawan untuk saling dikomunikasikan dalam kegiatan seminar atau ditulis 
dalam artikel ilmiah (Tall et al., 2011). Oleh karena itu, mahasiswa perlu dilatih pembuktian matematika sehingga mampu memahami struktur bangunan matematika formal.

Penelitian yang ada telah mengungkapkan bahwa kebanyakan siswa ataupun mahasiswa mengalami kesulitan dalam mengonstruksi bukti matematis (Moore, 1994; Gibson, 1998; Weber, 2001; Sowder \& Harel, 2003). Moore (1994) mengungkapkan ada 7 kesulitan yang dialami mahasiswa dalam mengkonstruksi bukti, yaitu : (1) mahasiswa tidak mengetahui definisi objek atau konsep matematika tertentu yang dibutuhkan dalam pembuktian, (2) mahasiswa kurang memahami konsep, (3) concept image, mahasiswa tidak cukup dalam merekonstruksi bukti, (4) mahasiswa tidak mampu menggeneralisasi beberapa contoh kasus, (5) mahasiswa tidak tahu bagaimana mengunakan definisi yang ada, (6) mahasiswa mengalami kesulitan dalam menggunakan notasi dan bahasa matematis, dan (7) mahasiswa tidak tahu bagaimana memulai pembuktian. Penelitian lain, Gibson (1998) menjelaskan bahwa faktor-faktor yang menjadi kesulitan siswa dalam membuktikan pernyataan matematis terdiri dari pemahamannya tentang aturan bukti, pemahaman konsep, strategi dan teknis membuat bukti, dan beban kognitif (cognitive load).

Kemampuan membangun bukti yang dilakukan oleh mahasiswa sangat berkaitan dengan kemampuan pemahaman matematis yang dimilikinya. Beberapa penelitian mengungkapkan bahwa kemampuan membaca bukti matematis (proof reading) sangat diperlukan dalam memahami bukti matematis tersebut (Mamona-Downs \& Downs, 2005; Selden \& Selden, 2003). Penelitian lainnya menyatakan bahwa memahami bukti ditandai dengan kemampuan membangun bukti untuk teorema lain yang sejenis (Conradie \& Frith, 2000, Rowland, 2001). Adapun Mejía-Ramos et al. (2012) membuat suatu asesmen terhadap pemahaman bukti matematis yang terdiri dari pemahaman lokal dan pemahaman global. Pemahaman lokal berupa pemahaman terhadap: (1) makna istilah dan pernyataan bukti (meaning of the term and statement), (2) kelogisan pernyataan dan kerangka bukti (logical status of statement and proof framework), (3) pembenaran klaim (justification claim). Adapun pemahaman global yaitu pemahaman terhadap: (1) ringkasan bukti melalui ide tingkat tinggi (summarizing via high level idea), (2) identifikasi struktur modular (identify the modular structure), (3) ilustrasi dengan contoh (illustrating with example), dan (4) transfer ide atau metode pembuktian 
pada konteks yang lain (transferring the general idea or method to another context).

Berdasarkan fakta empiris dan disesuaikan dengan asesmen yang diajukan oleh Mejía-Ramos et al. (2012), pemahaman bukti formal matematis para mahasiswa dapat diklasifikasikan menjadi: (1) pemahaman global yang bersifat holistik, (2) pemahaman global yang bersifat parsial, dan (3) pemahaman lokal yang bersifat parsial. Holistik mengandung keseluruhan makna dan konsep matematis yang dibutuhkan dalam mengonstruksi bukti matematis dapat dipahami oleh mahasiswa. Adapun parsial menunjukkan beberapa makna dan konsep matematis yang belum dipahami oleh mahasiswa. Dengan demikian pemahaman matematis sangat menentukan keberhasilan mahasiswa dalam mengonstruksi bukti matematis. Oleh karena itu, artikel ini bertujuan untuk mendeskripsikan karakteristik pemahaman mahasiswa dalam mengonstruksi bukti matematis.

\section{METODE PENELITIAN}

Penelitian ini menggunakan pendekatan kualitatif, sesuai dengan karakteristik yang diteliti. Penelitian ini dilakukan pada mahasiswa tingkat ke-3 Jurusan Pendidikan Matematika salah satu perguruan tinggi negeri di Banten. Data diambil dengan cara satu per satu mahasiswa diberi Tugas Pembuktian Matematis (TPM) dan diminta menyelesaikan secara think-aloud. Dengan cara seperti itu, akhirnya diperoleh sebanyak 26 mahasiswa yang terlibat dalam penelitian ini. Prosedur pemilihan subjek secara detil dijelaskan pada Gambar 2.

Adapun instrumen penelitian ini berupa lembar tugas pembuktian matematis dan pedoman wawancara. Wawancara bersifat terbuka untuk mengetahui respon dan mengklarifikasi jawaban mahasiswa terhadap konstruksi bukti matematis yang dibangun.



Gambar 1. Instrumen Tugas Pembuktian Matematis (TPM) 
Diagram alur pemilihan subjek penelitian terlihat pada Gambar 2.

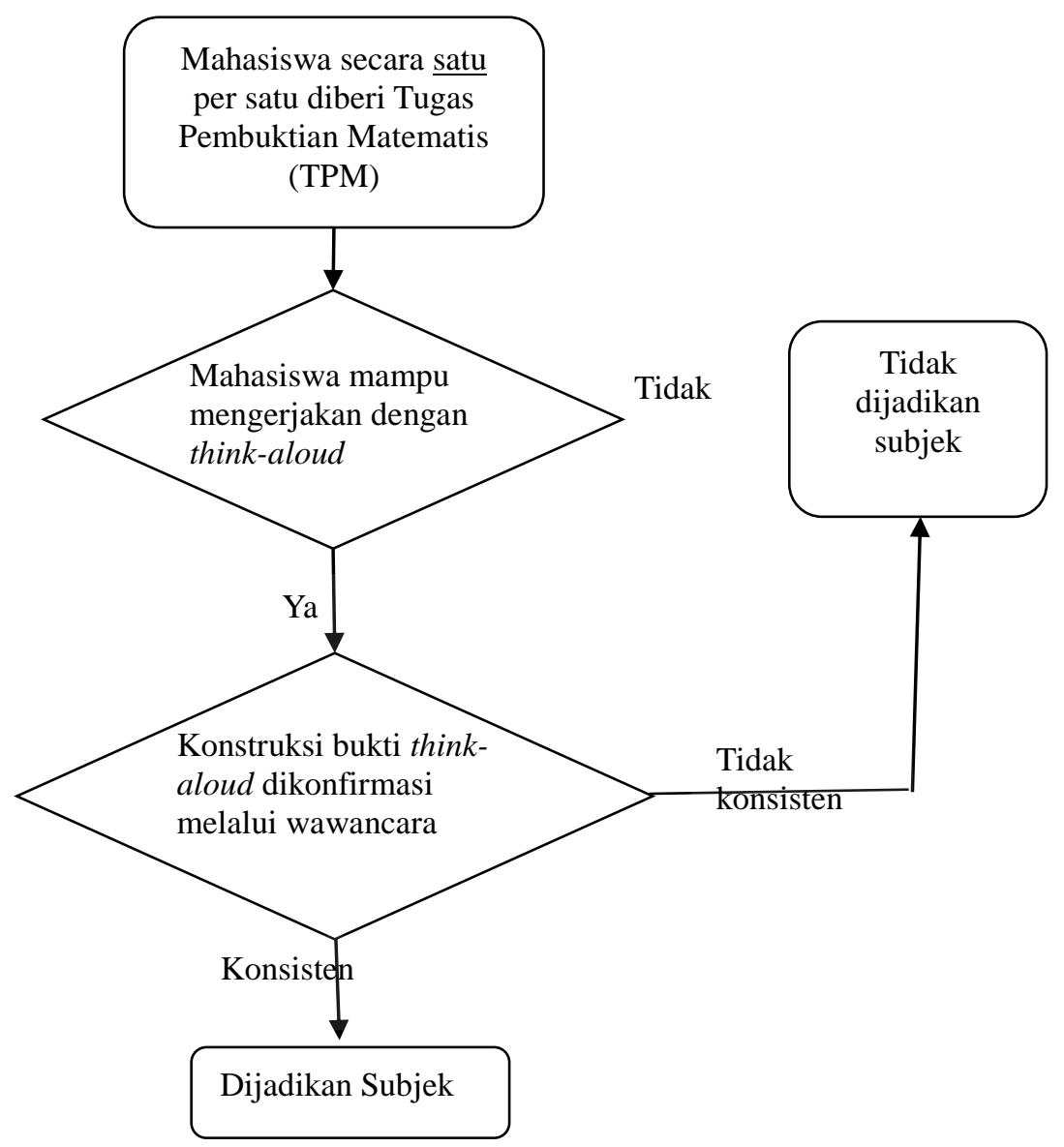

Gambar 2. Pemilihan Subjek Penelitian

\section{HASIL DAN PEMBAHASAN}

Proses pemilihan subjek telah dilakukan kepada 26 mahasiswa di salah satu perguruan tinggi di daerah Banten. Untuk mengetahui pemahaman bukti yang dikonstruksi oleh para mahasiswa dilakukan analisis menggunakan model pemahaman dari Mejia-Ramos et al. (2012). Berdasarkan asesmen tersebut, pemahaman bukti formal matematis dari 26 mahasiswa diklasifikasikan menjadi: (1) sebanyak 5 mahasiswa termasuk tipe global-holistik, mereka memiliki pemahaman global yang bersifat holistik, (2) sejumlah 11 mahasiswa tergolong tipe global-parsial, yaitu memiliki pemahaman global yang bersifat parsial, dan (3) sebanyak 10 mahasiswa termasuk tipe lokal-parsial, yaitu memiliki pemahaman lokal yang bersifat parsial. Selanjutnya, tiap-tiap tipe pemahaman tersebut dideskripsikan pemahaman subjek 
dalam mengonstruksi bukti sebanyak 2 mahasiswa.

Untuk mengetahui pemahaman bukti yang dikonstruksi mahasiswa tipe globalholistik dideskripsikan pemahaman bukti S1 dan S2 sebagai berikut. Berikut merupakan hasil konstruksi bukti S1 dan S2.

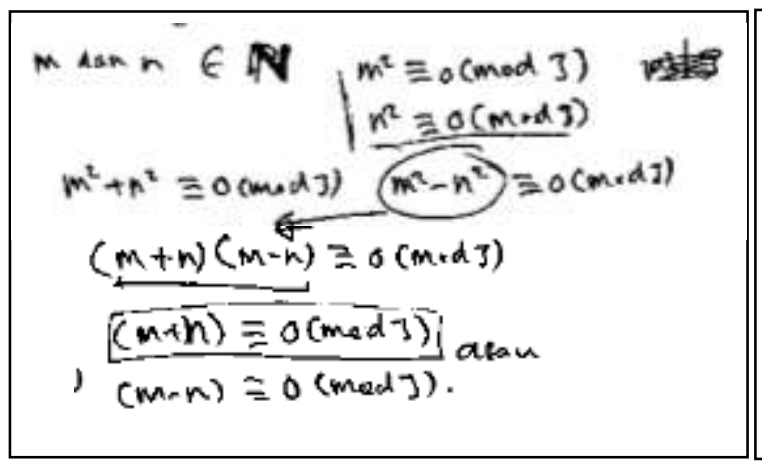

(a) Konstruksi Bukti S1

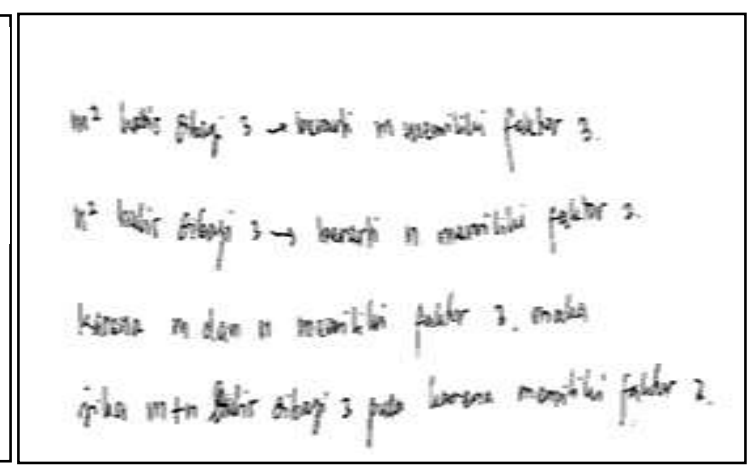

(b) Konstruksi Bukti S2

Gambar 3. Konstruksi Bukti dengan Pemahaman Tipe Global-Holistik

Karakteristik pemahaman bukti mahasiswa pada tipe ini merupakan pemahaman yang lengkap. Hal tersebut karena pemahaman bukti yang bersifat lokal (komponen nomer 1-4) maupun pemahaman bukti yang bersifat global (komponen nomer 5-7) terpenuhi oleh kedua subjek ini (Mejia-Ramos et al., 2012). Oleh karena itu, baik S1 dan S2 mampu mengonstruksi bukti dengan benar.

Tabel 1. Karakteristik Pemahaman Bukti Tipe Global-Holistik

\begin{tabular}{|c|c|c|c|}
\hline No. & $\begin{array}{l}\text { Komponen } \\
\text { Pemahaman Bukti }\end{array}$ & Subjek-S1 & Subjek-S2 \\
\hline 1 & $\begin{array}{l}\text { Kelogisan } \\
\text { Pernyataan dan } \\
\text { Kerangka Bukti }\end{array}$ & $\begin{array}{l}\text { Bukti langsung } \\
\text { menggunakan konsep } \\
\text { kekongruenan dengan } \\
\text { bilangan modulo. }\end{array}$ & $\begin{array}{l}\text { Bukti langsung } \\
\text { menggunakan konsep } \\
\text { faktor pembagi suatu } \\
\text { bilangan bulat. }\end{array}$ \\
\hline 2 & Pembenaran Klaim & $\begin{array}{l}\text { Membuat } 5 \text { klaim yang } \\
\text { bernilai benar. }\end{array}$ & $\begin{array}{l}\text { Membuat } 5 \text { klaim yang } \\
\text { bernilai benar. }\end{array}$ \\
\hline 3 & $\begin{array}{l}\text { Makna Istilah dan } \\
\text { Pernyataan Buktis }\end{array}$ & $\begin{array}{l}\text { - Bilangan bulat } \\
\text { - Bilangan kuadrat } \\
\text { - Bilangan yang habis } \\
\text { dibagi } 3 \\
\text { - Kekongruenan bilangan } \\
\text { modulo }\end{array}$ & $\begin{array}{l}\text { - Bilangan bulat } \\
\text { - Bilangan kuadrat } \\
\text { - Bilangan yang habis } \\
\text { dibagi } 3\end{array}$ \\
\hline 4 & $\begin{array}{l}\text { Meringkas melalui } \\
\text { ide tingkat tinggi }\end{array}$ & $\begin{array}{l}\text { - Menunjukkan jika } m^{2} \text { dan } \\
n^{2} \text { habis dibagi } 3 \text { maka } \\
m^{2}-n^{2} \text { habis dibagi } 3 \\
\text { - Menunjukkan jika } m^{2}-n^{2} \\
\text { habis dibagi } 3 \text { maka } \\
(m+n)(m-n) \text { habis dibagi }\end{array}$ & $\begin{aligned} \text { - } & \text { Menunjukkan jika } m^{2} \\
& \text { habis dibagi } 3 \text { maka } 3 \\
& \text { merupakan faktor } \\
& \text { pembagi dari } m \\
\text { - } & \text { Menunjukkan jika } 3 \\
& \text { merupakan faktor dari }\end{aligned}$ \\
\hline
\end{tabular}




\begin{tabular}{|c|c|c|c|}
\hline No. & $\begin{array}{l}\text { Komponen } \\
\text { Pemahaman Bukti }\end{array}$ & Subjek-S1 & Subjek-S2 \\
\hline & & $\begin{array}{l}3 \\
- \\
\text { Menunjukkan jika } \\
(m+n)(m-n) \text { habis dibagi } \\
3 \text { maka } m+n \text { habis dibagi } \\
\text { 3. }\end{array}$ & $\begin{array}{l}m \text { maka } m \text { habis dibagi } \\
\text { 3. } \\
\text { - } \text { Menunjukkan jika } n^{2} \\
\text { habis dibagi } 3 \text { maka } 3 \\
\text { merupakan faktor } \\
\text { pembagi dari } n \text {. } \\
\text { - } \text { Menunjukkan jika } 3 \\
\text { merupakan faktor dari } \\
n \text { maka } n \text { habis dibagi } 3 \\
\text { - Menunjukkan } m+n \\
\text { habis dibagi } 3 .\end{array}$ \\
\hline 5 & $\begin{array}{l}\text { Mengidentifikasi } \\
\text { Struktur Modular }\end{array}$ & $\begin{array}{l}\text { Ada Teorema } \\
\text { - Jika a|b dan a|c maka a|b- } \\
\text { c, a|b+c. } \\
\text { - Jika c|ab maka c|a atau } \\
\text { c|b. }\end{array}$ & Ada Teoremanya. \\
\hline 6 & $\begin{array}{l}\text { Mengilustrasikan } \\
\text { dengan Contoh }\end{array}$ & $\begin{array}{l}\text { - Memberikan contoh } \\
m^{2}=6^{2} \text { dan } n^{2}=3^{2}\end{array}$ & $\begin{array}{l}\text { - Memberikan contoh } \\
m^{2}=9 \text { dan } n^{2}=36\end{array}$ \\
\hline 7 & $\begin{array}{l}\text { Menggunakan ide } \\
\text { atau metode pada } \\
\text { konsteks lain }\end{array}$ & $\begin{array}{l}\text { Awalnya menyatakan bahwa } \\
\text { "Jika } m^{2} \text { dan } n^{2} \text { habis dibagi } \\
4 \text { maka } m+n \text { habis dibagi } 4 " \\
\text { merupakan pernyataan yang } \\
\text { benar, namun ketika diminta } \\
\text { untuk memberikan } \\
\text { contohya, } S 1 \text { mencoba } m=2 \\
\text { dan } n=4 \text { yang merupakan } \\
\text { counter-example dari } \\
\text { pernyataan tersebut. Dengan } \\
\text { cepat, S1 menyadari } \\
\text { kesalahan dan menyatakan } \\
\text { bahwa pernyatan tersebut } \\
\text { salah. }\end{array}$ & $\begin{array}{l}\text { Awalnya menyatakan } \\
\text { bahwa "Jika } m^{2} \text { dan } n^{2} \\
\text { habis dibagi } 4 \text { maka } m+n \\
\text { habis dibagi 4" } \\
\text { merupakan pernyataan } \\
\text { yang benar, namun ketika } \\
\text { diminta untuk } \\
\text { memberikan contohya, S2 } \\
\text { menemukan } m=2 \text { dan } n=4 \\
\text { yang merupakan counter- } \\
\text { example dari pernyataan } \\
\text { tersebut. Dengan cepat, } \\
\text { S1 menyadari kesalahan } \\
\text { nya. }\end{array}$ \\
\hline
\end{tabular}

Berdasarkan pendapat Polya, pemahaman subjek tersebut sudah berada pada tingkat intuitif (intuitive) karena telah mampu mengonstruksi bukti sendiri terkait teorema yang diberikan (Meel, 2003). Hal tersebut mencerminkan bahwa tiga pengetahuan dalam memahami matematika, yaitu: aplikasi (applications), makna (meanings), dan hubungan logika (logical relationship) telah ada pada pikiran kedua subjek tipe berpikir ini (Lehman, 1977). Adapun menurut Skemp (1976), tipe pemahaman subjek ini termasuk pemahaman relasional. Sedangkan menurut Pirie dan Kieren (1989), pemahaman subjek pada tipe berpikir ini sudah mencapai layerinventing. Oleh karena itu, pemahaman konstruksi bukti tipe ini dinamai dengan pemahaman 
global-holistik.

Untuk mengetahui pemahaman bukti yang dikonstruksi mahasiswa tipe globalparsial dideskripsikan pemahaman bukti S3 dan S4 sebagai berikut. Berikut merupakan hasil konstruksi bukti S3 dan S4.
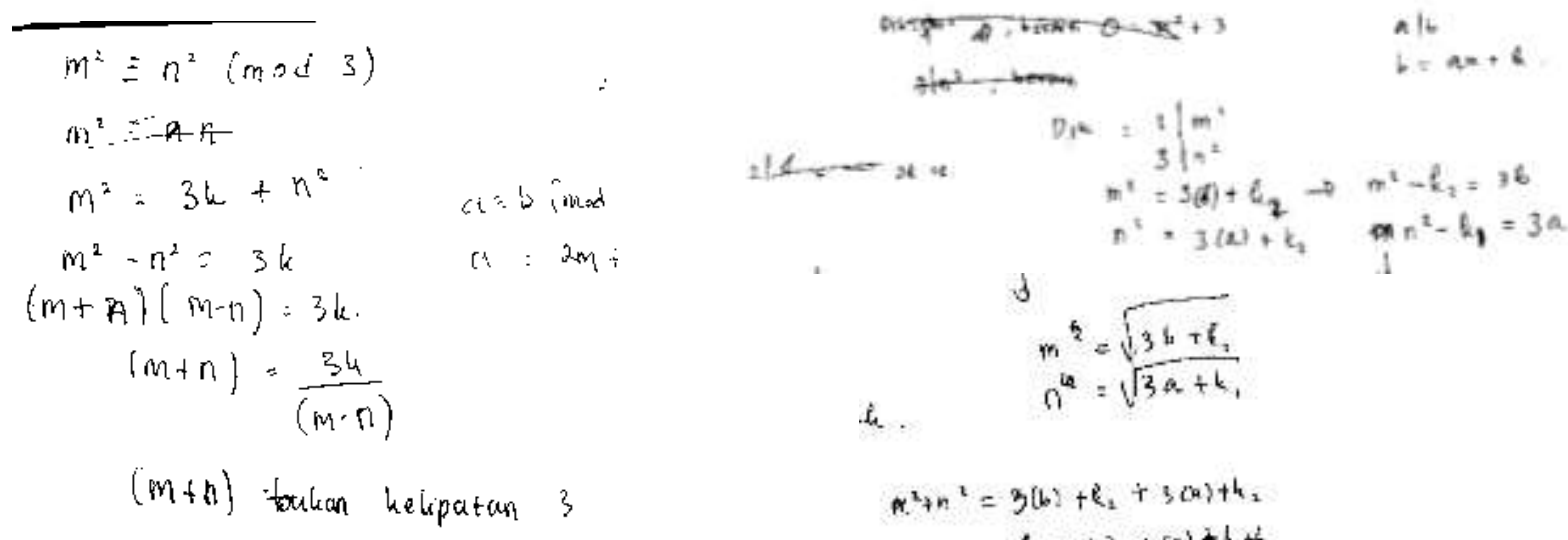

(a) Konstruksi Bukti S3

(b) Konstruksi Bukti S4

Gambar 4. Konstruksi Bukti dengan Pemahaman Tipe Global-Parsial

Komponen pemahaman bukti mahasiswa pada tipe ini merupakan pemahaman yang kurang lengkap. Hal tersebut karena pemahaman bukti yang bersifat lokal maupun pemahaman bukti yang bersifat global ada yang pemahaman yang kurang tepat dilakukan kedua subjek ini (Mejia-Ramos et al., 2012). Hal itu terjadi pada adanya klaim yang salah dan tidak munculnya pemahaman tentang identifikasi konstruksi bukti secara modular. 
Tabel 2. Karakteristik Pemahaman Bukti Tipe Global-Parsial

\begin{tabular}{|c|c|c|c|}
\hline No. & $\begin{array}{l}\text { Komponen } \\
\text { Pemahaman Bukti }\end{array}$ & Subjek-S3 & Subjek-S4 \\
\hline 1 & $\begin{array}{l}\text { Kelogisan } \\
\text { Pernyataan dan } \\
\text { Kerangka Bukti }\end{array}$ & $\begin{array}{l}\text { Bukti langsung } \\
\text { menggunakan konsep } \\
\text { kekongruenan dengan } \\
\text { bilangan modulo }\end{array}$ & $\begin{array}{l}\text { Bukti langsung } \\
\text { menggunakan konsep } \\
\text { faktor pembagi suatu } \\
\text { bilangan bulat }\end{array}$ \\
\hline 2 & Pembenaran Klaim & $\begin{array}{l}\text { Membuat } 1 \text { klaim yang } \\
\text { bernilai benar dan } 1 \text { klaim } \\
\text { yang salah }\end{array}$ & $\begin{array}{l}\text { Membuat } 1 \text { klaim yang } \\
\text { bernilai benar dan } 1 \text { klaim } \\
\text { yang salah }\end{array}$ \\
\hline 3 & $\begin{array}{l}\text { Makna Istilah dan } \\
\text { Pernyataan Bukti }\end{array}$ & $\begin{array}{l}\text { - Biangan bulat } \\
\text { - Bilangan kuadrat } \\
\text { - Bilangan yang habis } \\
\text { dibagi } 3 \\
\text { - Kekongruenan bilangan } \\
\text { modulo }\end{array}$ & $\begin{array}{l}\text { - Biangan bulat } \\
\text { - Bilangan kuadrat } \\
\text { - Bilangan yang habis } \\
\text { dibagi } 3\end{array}$ \\
\hline 4 & $\begin{array}{l}\text { Meringkas bukti } \\
\text { melalui ide tingkat } \\
\text { tinggi }\end{array}$ & $\begin{array}{l}\text { - Menunjukkan jika } m^{2} \text { dan } \\
n^{2} \text { habis dibagi } 3 \text { maka } \\
m^{2}-n^{2} \text { habis dibagi } 3 \\
\text { - Menunjukkan jika } m^{2}-n^{2} \\
\text { habis dibagi } 3 \text { maka } \\
\quad(m+n)(m-n) \text { habis dibagi } \\
3\end{array}$ & $\begin{aligned} & \text { - Menunjukkan jika } m^{2} \\
& \text { habis dibagi } 3 \text { maka } \\
& m^{2}=3 b+k_{2} \\
& \text { - Menunjukkan jika } m^{2} \\
& \text { habis dibagi } 3 \text { maka } \\
& n^{2}=3 a+k_{1} \\
& \text { - } \text { Menunjukkan } \\
& m+n=\sqrt{3 a+k_{2}}+ \\
& \sqrt{3 b+k_{1}}\end{aligned}$ \\
\hline 5 & $\begin{array}{l}\text { Mengidentifikasi } \\
\text { Struktur Modular }\end{array}$ & - Tidak muncul & Tidak muncul \\
\hline 6 & $\begin{array}{l}\text { Mengilustrasikan } \\
\text { dengan Contoh }\end{array}$ & $\begin{array}{l}\text { Salah dalam memberikan } \\
\text { contoh } m=2 \text { dan } n=7 \\
\text { karena menyakini } \\
\text { pernyataan tersebut salah. }\end{array}$ & - $m=9$ dan $n=3$ \\
\hline 7 & $\begin{array}{l}\text { Menggunakan ide } \\
\text { atau metode } \\
\text { pembuktian pada } \\
\text { konteks lain }\end{array}$ & $\begin{array}{l}\text { S3 menyatakan bahwa "Jika } \\
m^{2} \text { dan } n^{2} \text { habis dibagi } 4 \\
\text { maka } m+n \text { habis dibagi } 4 \text { " } \\
\text { merupakan pernyataan yang } \\
\text { salah, karena pernyataan } \\
\text { sebelumnya diyakini salah } \\
\text { juga. Selain itu S3 mencoba } \\
m=2 \text { dan } n=4 \text { yang } \\
\text { merupakan counter-example } \\
\text { dari pernyataan tersebut. }\end{array}$ & $\begin{array}{l}\text { S4 menyatakan bahwa } \\
\text { "Jika } m^{2} \text { dan } n^{2} \text { habis } \\
\text { dibagi } 4 \text { maka } m+n \text { habis } \\
\text { dibagi } 4 \text { " merupakan } \\
\text { pernyataan yang benar. }\end{array}$ \\
\hline
\end{tabular}

Berdasarkan pendapat Polya, pemahaman subjek tersebut sudah berada pada tingkat rasional (rational) karena menyakini tugas yang diberikan adalah benar, namun belum mampu membuktikannya (Meel, 2003). Hal tersebut mencerminkan bahwa kurangnya pengetahuan tentang makna (meanings). Padahal dalam memahami 
matematika terdiri dari pengetahuan aplikasi (applications), makna (meanings), dan logika (logical relationship) (Lehman, 1977). Adapun menurut Skemp (1976), tipe pemahaman subjek ini termasuk pemahaman relasional, namun belum sempurna mencapai kesimpulan akhir. Sedangkan menurut Pirie dan Kieren (1989), pemahaman subjek pada tipe berpikir ini sudah mencapai layerobserving. Oleh karena itu, pemahaman konstruksi bukti tipe ini dinamai dengan pemahaman global-parsial.

Untuk mengetahui pemahaman bukti yang dikonstruksi mahasiswa tipe lokalparsial dideskripsikan pemahaman bukti S5 dan S6 sebagai berikut. Berikut merupakan hasil konstruksi bukti S5 dan S6.

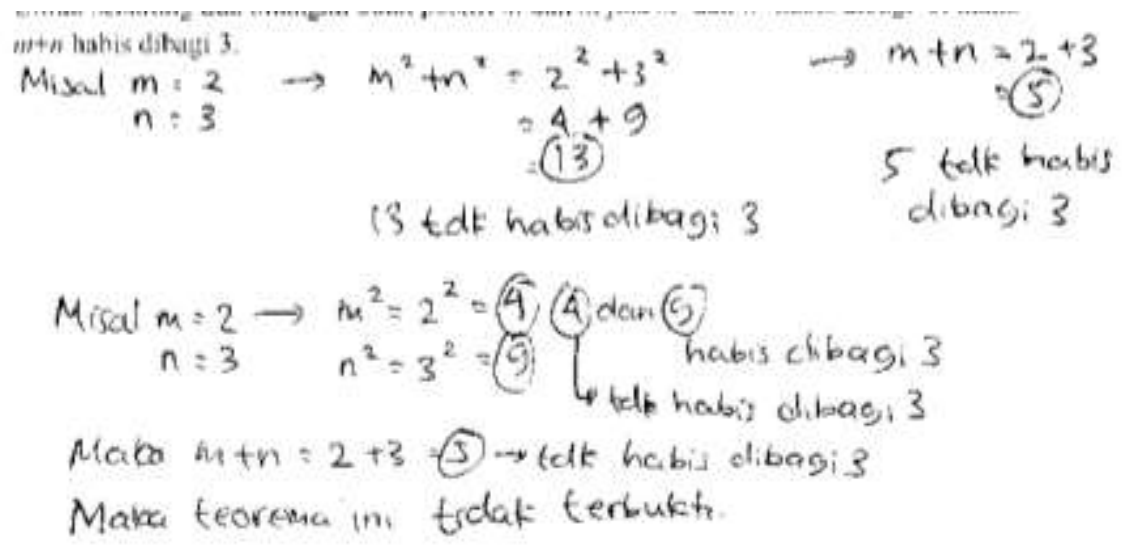

(a) Konstruksi Bukti S5
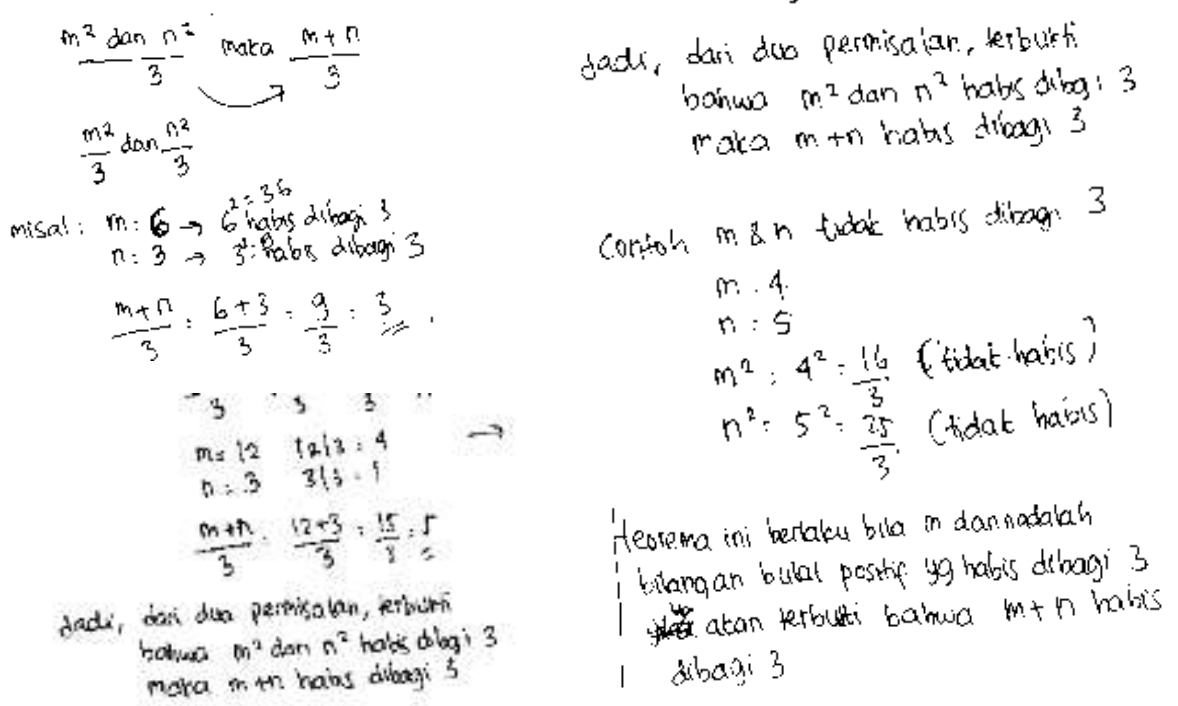

(b) Konstruksi Bukti S6

Gambar 4. Konstruksi Bukti dengan Pemahaman Tipe Global-Parsial

Komponen pemahaman bukti mahasiswa pada tipe ini merupakan pemahaman 
yang tidak lengkap. Hal tersebut karena pemahaman bukti yang bersifat lokal maupun pemahaman bukti yang bersifat holistik banyak yang tidak tepat dilakukan kedua subjek ini (Mejia-Ramos et al., 2012). Hal itu terjadi karena kedua subjek ini bernalar secara induktif dan mengalami kesulitan berpikir deduktif (Recio \& Godino, 2001). Hal ini dilihat dari adanya klaim yang salah, langkah-langkah besar dalam mengonstruksi bukti juga tidak muncul, tidak munculnya pemahaman tentang identifikasi konstruksi bukti secara modular, memberikan contoh kasus yang salah, serta tidak mampu menggunakan pola pikir bukti tersebut pada konteks yang lain .

Tabel 3. Karakteristik Pemahaman Bukti Tipe Induktif-Parsial

\begin{tabular}{|c|c|c|c|}
\hline No. & Komponen Bukti & Subjek-S5 & Subjek-S6 \\
\hline 1 & $\begin{array}{l}\text { Kelogisan } \\
\text { Pernyataan dan } \\
\text { Kerangka Bukti }\end{array}$ & Berpikir induktif & Berpikir induktif \\
\hline 2 & Pembenaran Klaim & $\begin{array}{l}\text { Membuat } 2 \text { klaim yang } \\
\text { salah }\end{array}$ & $\begin{array}{l}\text { Membuat klaim yang } \\
\text { bersifat klarifikasi saja }\end{array}$ \\
\hline 3 & $\begin{array}{l}\text { Makna Istilah dan } \\
\text { Pernyataan Buktis }\end{array}$ & $\begin{array}{l}\text { - Biangan bulat } \\
\text { - Bilangan yang habis } \\
\text { dibagi } 3 \\
\text { - Deskripsi masih } \\
\text { sederhana }\end{array}$ & $\begin{array}{l}\text { - } \text { Biangan bulat } \\
\text { - Bilangan yang habis } \\
\text { dibagi } 3 \\
\text { - Deskripsi masih } \\
\text { sederhana }\end{array}$ \\
\hline 4 & $\begin{array}{l}\text { Meringkas bukti } \\
\text { melalui ide tingkat } \\
\text { tinggi }\end{array}$ & - Tidak muncul & - Tidak Muncul \\
\hline 5 & $\begin{array}{l}\text { Mengidentifikasi } \\
\text { Struktur Modular }\end{array}$ & - Tidak muncul & Tidak muncul \\
\hline 6 & $\begin{array}{l}\text { Mengilustrasikan } \\
\text { dengan Contoh }\end{array}$ & $\begin{array}{l}\text { - } m=3 \text { dan } n=6 \text {, akan tetapi } \\
\text { menentukan } m \text { dan } n \text { nya } \\
\text { terlebih dahulu baru } m^{2} \\
\text { dan } n^{2} \text { nya. }\end{array}$ & $\begin{array}{l}m=6 \text { dan } n=3 \text {, akan tetapi } \\
\text { menentukan } m \text { dan } n \text { nya } \\
\text { terlebih dahulu baru } m^{2} \\
\text { dan } n^{2} \text { nya. }\end{array}$ \\
\hline 7 & $\begin{array}{l}\text { Menggunakan ide } \\
\text { atau metode } \\
\text { pembuktian pada } \\
\text { konteks lain }\end{array}$ & $\begin{array}{l}\text { S5 menyatakan bahwa "Jika } \\
m^{2} \text { dan } n^{2} \text { habis dibagi } 4 \\
\text { maka } m+n \text { habis dibagi } 4 \text { " } \\
\text { merupakan pernyataan yang } \\
\text { benar, dengan alasan hanya } \\
\text { memberikan contoh kasus } \\
\text { saja. }\end{array}$ & $\begin{array}{l}\text { S6 menyatakan bahwa } \\
\text { "Jika } m^{2} \text { dan } n^{2} \text { habis } \\
\text { dibagi } 4 \text { maka } m+n \text { habis } \\
\text { dibagi } 4 \text { " merupakan } \\
\text { pernyataan yang benar, } \\
\text { yang hanya memberikan } \\
\text { contoh kasus saja. }\end{array}$ \\
\hline
\end{tabular}

Berdasarkan pendapat Polya, pemahaman subjek tersebut sudah berada pada tingkat induktif (inductive) karena hanya mampu memberikan contoh kasus sederhana yang memenuhi pernyataan yang dibuktikan (Meel, 2003). Hal tersebut mencerminkan kurangnya pengetahuan tentang aplikasi (applications), makna (meanings), dan logika 
(logical relationship) dalam memahami matematika (Lehman, 1977). Adapun menurut Pirie dan Kieren (1989), pemahaman subjek pada tipe berpikir ini sudah mencapai layerimage having. Oleh karena itu, pemahaman konstruksi bukti tipe ini dinamai dengan pemahaman lokal-parsial.

\section{SIMPULAN DAN SARAN}

Karakteristik tipe pemahaman bukti global-holistik ialah: (1) pemahaman subjek tersebut sudah berada pada tingkat intuitif (intuitive); (2) pemahaman subjek sudah mencerminkan tiga pengetahuan dalam memahami matematika, yaitu: aplikasi (applications), makna (meanings), dan logika (logical relationship); (3) pemahaman subjek ini termasuk pemahaman relasional; (4) pemahaman subjek pada tipe berpikir ini sudah mencapai layerinventing. Karakteristik tipe pemahaman bukti global-parsial ialah: (1) pemahaman subjek tersebut sudah berada pada tingkat rasional (rational); (2) pemahaman subjek terkait makna (meanings) masing kurang; (3) pemahaman subjek ini termasuk pemahaman relasional; (4) pemahaman subjek pada tipe berpikir ini sudah mencapai layerobserving. Sedangkan karakteristik tipe pemahaman bukti lokal-parsial ialah: (1) pemahaman subjek tersebut masih berada pada tingkat induktif (inductive); (2) pemahaman subjek terkait tiga pengetahuan dalam memahami matematika masih kurang; (3) pemahaman subjek ini termasuk pemahaman instrumental; (4) pemahaman subjek pada tipe berpikir ini sudah mencapai layerimage having.

Saran-saran terkait dengan penelitian lanjutan ialah perlunya kajian berbagai strategi ataupun model pembelajaran yang tepat dan sesuai dengan pemahaman mahasiswa berdasarkan klasifikasi pemahaman bukti mahasiswa. Strategi ataupun model pembelajaran tersebut diharapkan mampu mengatasi kesulitan mahasiswa dalam mengonstruksi bukti matematis.

\section{DAFTAR RUJUKAN}

Alcock, L., \& Inglis, M. (2008). Doctoral students' use of examples in evaluating and proving conjectures. Educational Studies in Mathematics, 69, 111-129.

Alcock, L. \& Weber, K. (2004). Semantic and syntactic proof productions. Educational Studies in Mathematics, 56, 209-234.

Conradie, J., \& Frith, J. (2000). Comprehension tests in mathematics. Educational Studies in Mathematics, 42, 225-235. 
Galbraith, P.L. (1981). Aspects of proving: A clinical investigation of process. Educational Studies in Mathematics, 12(1), 1-28.

Gibson, D. (1998). Students' use of diagrams to develop proofs in an introductory analysis course. Students' proof schemes. In E. Dubinsky, A. Schoenfeld, \& J. Kaput (Eds.), Research in Collegiate Mathematics Education, III, 284-307. Washington: AMS.

Larsen, S. \& Zandieh, M. (2008). Proofs and refutations in the undergraduate mathematics classroom. Educational Studies in Mathematics, 67(3), 205-216.

Lee, K. (2016). Students' proof schemes for mathematical proving and disproving of propositions. Journal of Mathematical Behavior 41, 26-44.

Lehman, H. (1977). On understanding mathematics. Educational Studies in Mathematics, 27 (2), 111-119.

Mamona-Downs, J., \& Downs, M. (2005). The identity of problem solving. The Journal of Mathematical Behavior, 24, 385-401.

Mejia-Ramos, J. P., Fuller, E., Weber, K., Rhoads K. \& Samkoff, A. (2012). An assessment model for proof comprehensionin undergraduate mathematics. Educational Studies in Mathematics 79, 3-18.

Meel, D. (2003). Models and theories of mathematical understanding: Comparing Pirie and Kieren's model of growth of mathematical understanding and APOS theory. CBMS Issue in Mathematics Education, 12.

Moore, R.C. (1994). Making the transition to formal proof. Educational Studies in mathematics, 27, 249-266.

Pirie, S. \& Kieren, T. (1989). A recursive theory of mathematical understanding. For the Learning of Mathematic, 9(3), 7-11.

Raman, M. (2003). Key ideas: What are they and how can they help us understand how people view proof? Educational Studies in Mathematics, 52(3), 319-325.

Recio, A. M. \& Godino, J. D. (2001). Institutional and personal meanings of mathematical proof. Educational Studies in Mathematics, 48(1), 83-99.

Rowland, T. (2001). Generic proofs in number theory. In S. Campbell \& R. Zazkis (Eds.), Learning and teaching number theory: Research in cognition and instruction (pp. 157-184). Westport: Ablex.

Selden, A. \& Selden, J. (2003). Validations of proofs considered as texts: can undergraduates tell whether an argument proves a theorem? Journal for Research in Mathematics Education, 34(1), 4-36. 
Skemp, R. R. (1976). Relational Understanding and Instrumental Understanding. Mathematics Teaching, 77, 20-26.

Sowder, L. \& Harel, G. (2003). Case studies of mathematics majors' proof understanding, production, and appreciation. Canadian Journal of Science, Mathematics and Technology Education, 3(2), 251-267.

Stylianides, A.J. \& Stylianides, G.J. (2009). Proof Constructions and Evaluations. Educational Studies in Mathematics, 72(2), 237-253.

Syamsuri, S., Purwanto, P., Subanji, S. \& Irawati, S. (2016). Characterization of Students Formal-Proof Construction in Mathematics Learning. Communications in Science and Technology, 1(2), 42-50.

Tall, D., Yevdokimov, O., Koichu, B., Whiteley, W., Kondratieva, M., \& Cheng, Y.H. (2011).The Cognitive Development of Proof.In In Hanna, G. and De Villiers, M. (Eds). ICMI 19: Proof and Proving in Mathematics Education, pp.13-49.

Weber, K. (2001). Student Difficulty in Constructing Proofs: The Need for Strategic Knowledge. Educational Studies in Mathematics, 48(1), 101-119.

Weber, K. (2012). Mathematicians' perspectives on their pedagogical practice with respect to proof. International Journal of Mathematical Education in Science and Technology, 43(4), 463-482.

Zazkis, D., Weber, K. \& Mejia-Ramos, J. P. (2015). Two proving strategies of highly successful mathematics major. Journal of Mathematical Behavior, 39, 11-27. 